\title{
The Striking Observations on Two Personal Protective Measures During COVID-19 Pandemic: Face Mask and Social Distance
}

\author{
Şükran Köse' ${ }^{1}$ iD, Yusuf Özbel² (iD \\ 1 Department of Clinical Microbiology and Infectious Diseases, University of Health Sciences, Tepecik Research and \\ Educational Hospital, İzmir, Turkey \\ 2 Department of Parasitology, Ege University School of Medicine, İmir, Turkey
}

T he COVID-19 outbreak continues to spread among people around the world, despite many measures taken by governments. Wearing a single-use mask, keeping social distance and hand hygiene are the main personal protective measures and need to be applied correctly by each person in the communities. These measures are very important, especially to prevent SARS-CoV-2 virus transmission from asymptomatic persons to other people of all ages $(1,2)$.

We did an observation among the people waiting outside during the 2020 national university admission examination in the examination areas of four different schools. The observation was done by four nurse school students using a standard written data collection form. The form included a table of mask types and a field for notes. Then, the results were transferred to the excel file, and ratios were calculated. A total of 2408 people, including students entering the exam, were observed in terms of the usage of face masks and keeping social distance. We noticed that $76.7 \%(n=1847)$ of the people were wearing a surgical mask while $15.7 \%$ ( $n=378$ ) of the people had no face mask (Table 1). We also checked the proper use of the masks among the people wearing different kinds of face masks $(n=2030)$ and observed that only $62.26 \%(n=1264)$ of the people were using the face masks properly, unfortunately. The improper use of mask was as follows: only mouth covered 6.15\%, under the chin $27.29 \%$, in the hand $7.83 \%$.

It has been observed that;

- $30 \%$ of the students came out without a mask at the end of the exam. Among the students wearing masks, $80 \%$ and $20 \%$ of them wore surgical masks and cloth masks, respectively.

- $\quad 95 \%$ of the students were seen to go out with a surgical mask in just one school.

Corresponding Author: Şükran Köse

E-mail: sukrankose@yahoo.com

Received: August 20, 2020 Accepted: November 14, 2020 Published: December 31, 2020

Suggested citation: Köse Ş, Özbel Y. The Striking Observations on Two Personal Protective Measures During COVID-19 Pandemic: Face Mask and Social Distance. Infect Dis Clin Microbiol 2020; 3: 187-188.

DOI: $10.36519 / \mathrm{idcm} .2020 .0022$ 
Table 1. Kinds of masks wearing by 2408 people

\begin{tabular}{|c|c|c|c|c|c|c|c|c|c|c|c|}
\hline \multicolumn{2}{|c|}{ Surgical Mask } & \multicolumn{2}{|c|}{ Black Mask* } & \multicolumn{2}{|c|}{ N95 Mask } & \multicolumn{2}{c|}{ Cloth Mask } & \multicolumn{2}{c|}{ Visors only } & \multicolumn{2}{c|}{ No Mask } \\
\hline $\mathrm{n}$ & $\%$ & $\mathrm{n}$ & $\%$ & $\mathrm{n}$ & $\%$ & $\mathrm{n}$ & $\%$ & $\mathrm{n}$ & $\%$ & $\mathrm{n}$ & $\%$ \\
\hline 1847 & 76.7 & 97 & 4.03 & 7 & 0.29 & 71 & 2.95 & 8 & 0.33 & 378 & 15.7 \\
\hline
\end{tabular}

*made by washable synthetic textile

- The use of masks by young children waiting outside with their families was the same as the way their families used.

- The correct use of masks among families waiting outside decreased after the exam started.

- Students' relatives waiting outside the school did not comply with the social distance, but the students who were taken to the school garden to enter the exam paid more attention to the social distance.

- The violation of the social distance rule reaches its maximum level, especially during the entrance and exit of the exam.

- Families waiting away from the school zone maintain social distance, but social distance cannot be maintained when they approach the school zone.
These observations revealed that almost half of the population are not using masks properly even in crowded places. The washable masks were detected in 168 (8.27\%) out of 2030 people. This can create a new issue that needs to be discussed, and society should be informed about the correct washing procedure for disinfection of these washable masks.

Despite all efforts made to increase the knowledge of the society (TV programs, public announcements, animations, newspaper articles, etc.), the lack in the implementation of the two simplest measures shows that the contribution of the society cannot be achieved in preventing the spread of the disease. We believe that these observational studies (without asking to the participants) should be increased to evaluate the contribution level of the people in the communities.
Peer-review: Externally peer-reviewed

Conflict of Interest: The authors have no conflict of interest to declare.
Financial Disclosure: The authors declared that this study has received no financial support.

Acknowledgement: We would like to thank to the nursery students Seheray Şahin, Büşra Çağlar, Deniz Tekin and Merve Cirit for filling the forms.

\section{REFERENCES}

1 Republic of Turkey Ministry of Health General Directorate of Public Health. COVID-19 Information Page. Available from: https://covid19bilgi.saglik.gov.tr/depo/toplumda-salgin-yonetimi/salgin-yonetimi-ve-calisma-rehberi/COVID-19 SALGIN YONETIMI VE CALISMA REHBERI.pdf

2 World Health Organization. Advice on the use of masks in the community, during home care and in healthcare settings in the context of the novel coronavirus (2019-nCoV) outbreak. 2020 April 6 [cited 2020 May 8]. Available from: https://www. who.int/publications-detail/advice-on-the-use-of-masks-inthe-community-during-home-care-and-inhealthcare-settings-in-the-context-of-the-novel-coronavirus-(2019-ncov)outbreak. 